\title{
Heterogeneity in friction strength of an active fault by incorporation of fragments of the surrounding host rock
}

\author{
Naoki Kato and Tetsuro Hirono*
}

\begin{abstract}
To understand the correlation between the mesoscale structure and the frictional strength of an active fault, we performed a field investigation of the Atera fault at Tase, central Japan, and made laboratory-based determinations of its mineral assemblages and friction coefficients. The fault zone contains a light gray fault gouge, a brown fault gouge, and a black fault breccia. Samples of the two gouges contained large amounts of clay minerals such as smectite and had low friction coefficients of approximately $0.2-0.4$ under the condition of $0.01 \mathrm{~m} \mathrm{~s}^{-1}$ slip velocity and $0.5-2.5 \mathrm{MP}$ confining pressure, whereas the breccia contained large amounts of angular quartz and feldspar and had a friction coefficient of 0.7 under the same condition. Because the fault breccia closely resembles the granitic rock of the hangingwall in composition, texture, and friction coefficient, we interpret the breccia as having originated from this protolith. If the mechanical incorporation of wall rocks of high friction coefficient into fault zones is widespread at the mesoscale, it causes the heterogeneity in friction strength of fault zones and might contribute to the evolution of fault-zone architectures.
\end{abstract}

Keywords: Atera fault, Fault gouge, Friction experiment, Fault-zone evolution

\section{Introduction}

The evolution of frictional strength during the seismic cycle is an important issue for seismology and earthquake prediction. Many laboratory studies have measured the coefficient of friction in faults at slip rates ranging from ultraslow $\left(10^{-9} \mathrm{~m} \mathrm{~s}^{-1}\right)$ to fast $\left(1 \mathrm{~m} \mathrm{~s}^{-1}\right)$ (e.g., Byerlee and Brace 1968; Byerlee 1978; Mizoguchi et al. 2007; Di Toro et al. 2011; Ikari et al. 2015). Coseismic reduction in fault strength, by thermal and tribological processes such as thermal pressurization (Sibson 1973) and powder lubrication (Reches and Lockner 2010), is also an important factor in the behavior of fault slip during earthquakes. The physical and chemical processes that produce this weakening have typically been investigated by integrating friction experiments with analyses of the products of friction (e.g., Wibberley and Shimamoto 2005; Han et al. 2007; Brantut et al. 2008; Boulton et al. 2012; Hirono

\footnotetext{
*Correspondence: hirono@ess.sci.ossaka-u.ac.jp Department of Earth and Space Sciences, Graduate School of Science, Osaka University, Toyonaka, Japan
}

et al. 2013). Only a handful of studies so far have clearly been examined the microstructures of experimental products (e.g., Brantut et al. 2008; Han et al. 2014). The postseismic recovery of fault strength (also fault healing) and the heterogeneity in fault strength are another problems that are closely related to the seismic potential and recurrence interval of fault slip, the source parameters of future earthquakes, such as stress drop, and the evolution of fault-zone architecture.

Healing rates have been estimated in active faults on the basis of an increase in seismic velocity from 1994 to 1998 after the 1992 Landers earthquake on the Johnson Valley fault, California (Li and Vidale 2001) and the changing direction of shear-wave splitting after the 1995 Kobe earthquake (Tadokoro and Ando 2002). Fault-healing processes have also been studied in laboratory experiments examining stick-slip behavior (Brace and Byerlee 1966), the strength increase in simulated fault gouge with respect to the contact duration at grain junctions (e.g., Dieterich 1972), shear load perturbations (Karner and Marone 2001), and crack sealing via fluid-assisted 
pressure solution compaction or mineral precipitation (e.g., Olsen et al. 1998; Bos and Spiers 2000; Muhuri et al. 2003; Niemeijer et al. 2008).

However, in natural fault gouges, complex mesoscale and microscale deformation structures (fabrics) are common, such as granulation, preferred grain orientation, Riedel and Y-shear planes, and fluidized granular flow (e.g., Borradaile 1981; Rutter et al. 1986; Niemeijer et al. 2012; Rowe and Griffith 2015). The composition of natural fault gouges also shows complex variation: Many gouges consist largely of clay minerals such as smectite and illite (e.g., Vrolijk and van der Pluijm 1999; Hirono et al. 2008a; Lockner et al. 2011), although sandy gouge has been reported in the major thrust in the Nankai Trough (Hirono et al. 2014a). Because understanding the role of microscale deformation structure (fabrics) and mineralogy in fault gouges is important for developing process-based models of friction, many experimental studies have been performed (e.g., Ikari et al. 2011). These have shown that mineralogical composition influences the strength and stability of a fault (e.g., Byerlee 1978; Shimamoto and Logan 1981; Brown et al. 2003; Faulkner et al. 2011; Ikari et al. 2011) and that the frictional strength is closely related to the evolution of deformation fabrics during slip (e.g., Collettini et al. 2009; Oohashi et al. 2015). However, relatively little is known about the role of mesoscale deformation structures in the slip behavior and evolution of faults, even though fault gouge may be substantial. For example, a fault gouge on the Taiwan Chelungpu fault is $13 \mathrm{~cm}$ thick and has a complex structure that includes localized slip zones (Ma et al. 2006; Hirono et al. 2008b).

The purpose of this study was to investigate the relationship between the friction coefficient and the zonal evolution of a fault gouge. Specifically, we documented the mineralogy, deformation structures, and friction coefficients of fault materials at a site on the active Atera fault in central Japan. In this paper, we present the results and discuss heterogeneous fault strength from a mesoscale perspective.

\section{Geological setting}

The left-lateral Atera fault system, extending $66 \mathrm{~km}$ in a NW-SE direction in Gifu Prefecture in central Japan (Fig. 1a), has been active since the early Quaternary within an E-W compressive stress field (Sugimura and

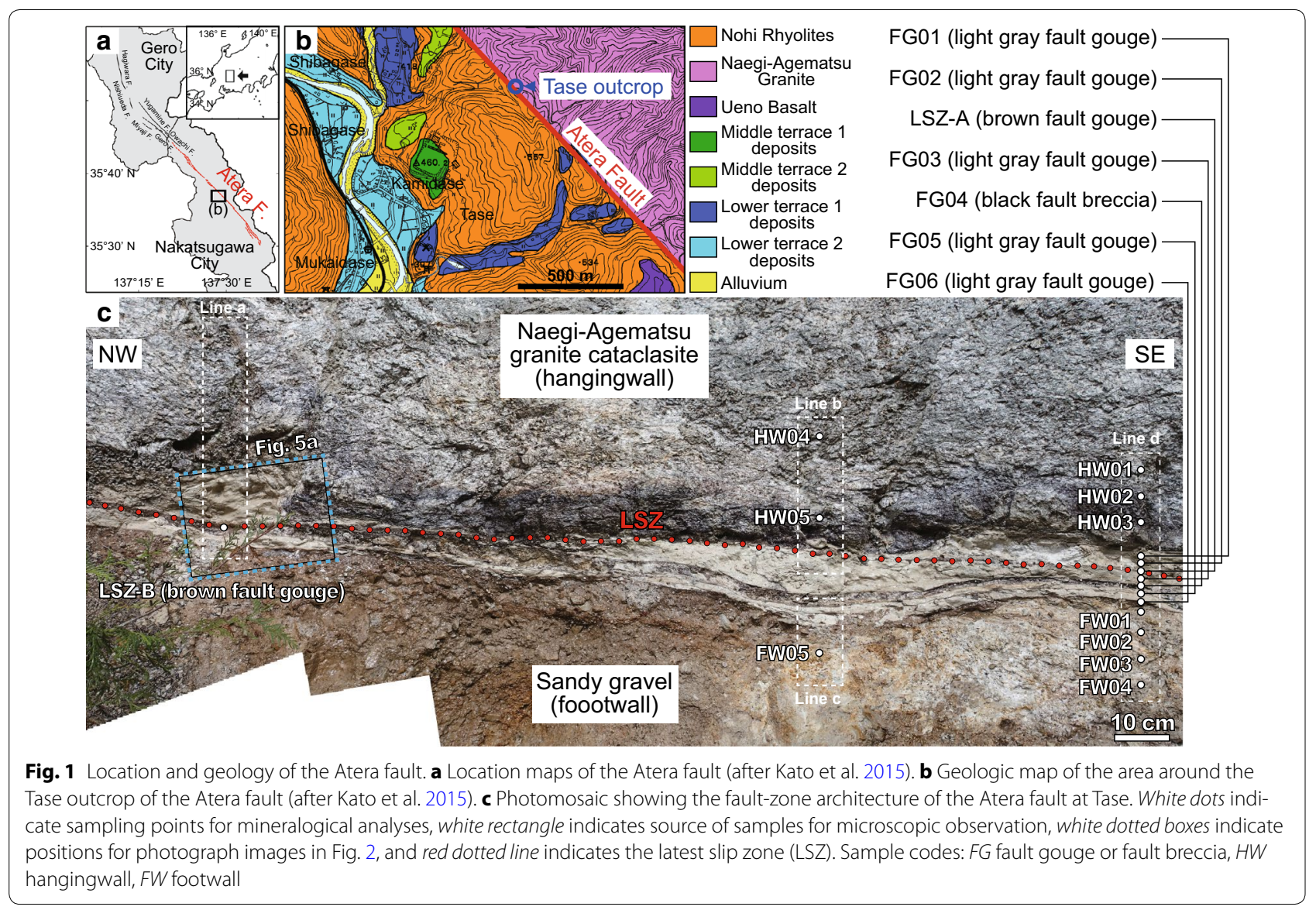




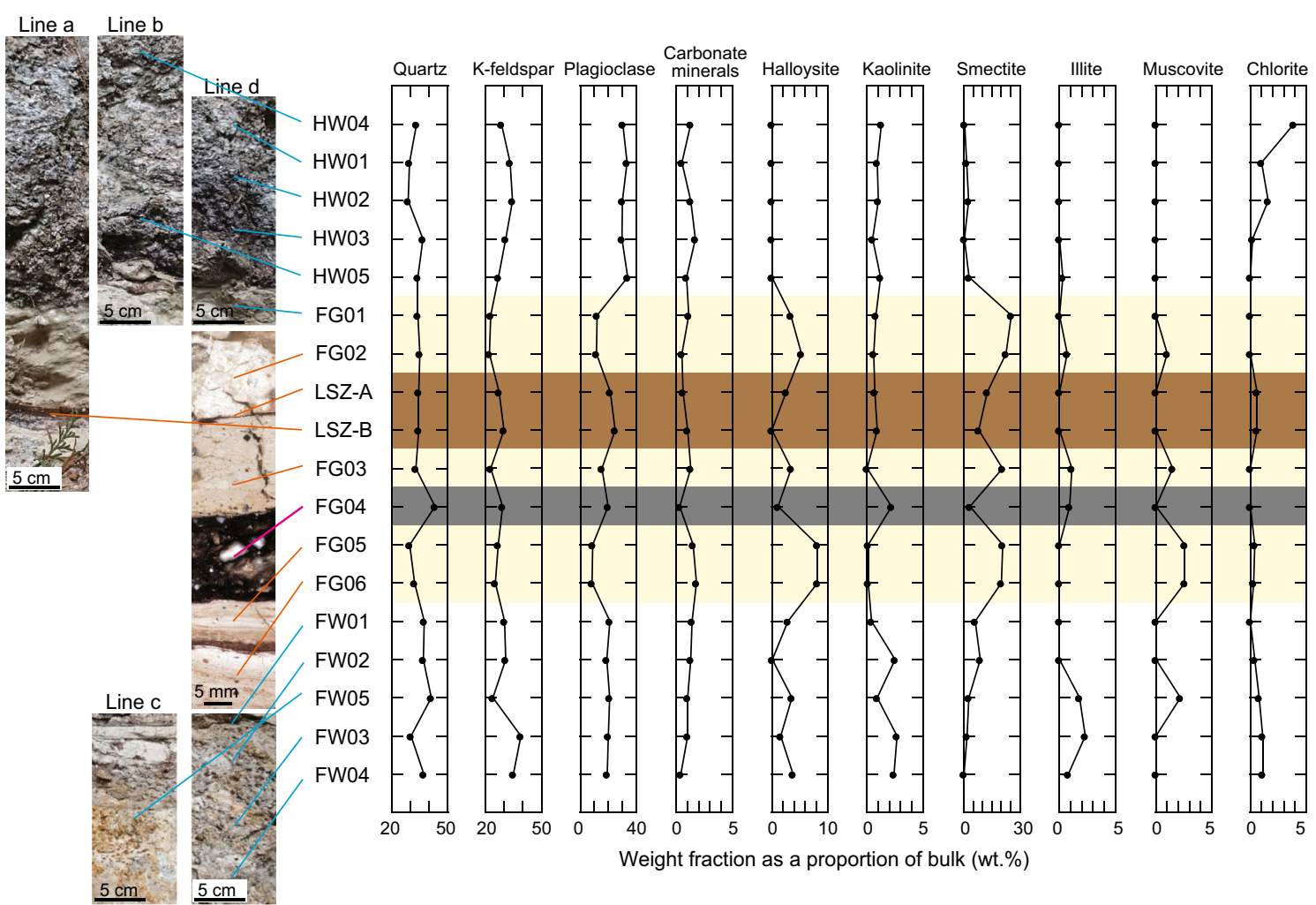

Fig. 2 Vertical profiles of mineral assemblages in the fault zone of the Atera fault. The yellow, brown, and gray areas represent light gray fault gouge, brown fault gouge, and black fault breccia, respectively. Mineral component data are from Kato et al. (2015). Sample and photograph image locations are shown in Fig. 1c. Note the variation in the horizontal axes of the profiles (Line d)

Matsuda 1965). Its latest activity has been correlated with the 1586 Tensho earthquake (Toda and Inoue 1994, 1995), and its average displacement rate has been estimated at $2.8 \mathrm{~mm}$ per year (Tsukuda et al. 1993). Around the village of Tase, the fault zone has a reverse shear sense with a $\mathrm{N} 38^{\circ} \mathrm{W}$ strike and $60^{\circ} \mathrm{N}$ dip. The hangingwall consists of the Late Cretaceous Naegi-Agematsu granite cataclasite, and the footwall consists of Quaternary sandy gravel (Fig. 1b). There, the fault zone contains a light gray fault gouge, a brown fault gouge, and a black fault breccia (Fig. 1c). The brown fault gouge has been identified as the latest slip zone, probably corresponding to the 1586 earthquake, because it cuts all other gouge layers without distortion (Kato et al. 2015). We collected 18 samples from the fault gouges and surrounding host rocks to investigate their mineralogy, deformation fabrics, and friction coefficients.

\section{Methods}

Mineral assemblages of the samples were previously analyzed by Kato et al. (2015) by means of X-ray diffraction spectra obtained by using an X'Pert PRO MPD spectrometer (Spectris PANalytical). The samples were blended with $\alpha$-alumina (25 wt\%) as an internal standard and mounted on a plate by the side-load method to minimize the preferred alignment of the phyllosilicates, and the mineral assemblages were determined by using the RockJock program (Eberl 2003).

Friction coefficients were measured by using a rotary shear apparatus (described in Mizoguchi et al. 2009). Approximately $500 \mathrm{mg}$ of water-saturated powdered host rock was placed between the ends of two cylinders of sandstone ( $25 \mathrm{~mm}$ diameter) and sealed in a polytetrafluoroethylene sleeve to prevent leaks. The experiments were performed at ambient humidity under normal stresses that were increased in $0.5 \mathrm{MPa}$ increments from 0.5 to $2.5 \mathrm{MPa}$. The friction coefficient has been shown to be generally velocity dependent and to have its peak value at velocities around $0.01 \mathrm{~m} \mathrm{~s}^{-1}$, independent of rock type (e.g., Di Toro et al. 2011; Niemeijer et al. 2012). In addition, values at high slip velocities of $0.1-1.0 \mathrm{~m} \mathrm{~s}^{-1}$ reflect the effects of weakening mechanisms such as powder lubrication (Reches and Lockner 2010) and thermal decomposition (Han et al. 2007). We thus adopted a velocity of $0.01 \mathrm{~m} \mathrm{~s}^{-1}$ to represent peak friction during earthquakes. The shear stress was measured with a slip 
displacement after a correction for friction between the rock cylinders and the sleeve (approximately 0.01 ), which was determined from the shear stress at zero normal stress.

Thin sections of the samples were carefully prepared after being impregnated with epoxy resin and polished and then observed under a petrographic microscope.

\section{Results}

The fault zone at Tase displays three structural zones that differ from one another in their mineral compositions (Fig. 2). The light gray fault gouge contains a small proportion of K-feldspar and plagioclase and a large amount of halloysite and smectite, compared with the mineral assemblage of the surrounding host rocks. The brown fault gouge (thought to have hosted the 1586 rupture) has slightly more smectite, and the black fault breccia does not show a marked difference in the mineral assemblage. These mineral compositions may be related to the elemental compositions reported by Kato et al. (2015), who found relatively high $\mathrm{Al}$ and $\mathrm{Mg}$ and low $\mathrm{Na}$ and $\mathrm{K}$ concentrations in the light gray fault gouge.

The frictional behaviors of five representative samples across the fault are shown in Fig. 3. The relationship of shear stress to normal stress was strongly linear (Fig. 3f), and the friction coefficients of the fault materials were as follows: hangingwall, 0.77; footwall, 0.78; light gray gouge, 0.19-0.24; brown fault gouge, 0.40 and 0.43 ; and black fault breccia, 0.70 (Fig. 4a). The friction coefficients of all samples were inversely related to the total clay mineral contents determined by the XRD-RockJock analysis (Fig. 4b).

\section{Discussion}

A typical fault-zone structure consists of a strain-localized core within a damage zone with densely distributed fractures, and the fault core usually corresponds to fault gouge at shallow levels in the crust (e.g., Biegel and Sammis 2004; Faulkner et al. 2010). However, in the Atera fault the fault zone includes the black fault breccia
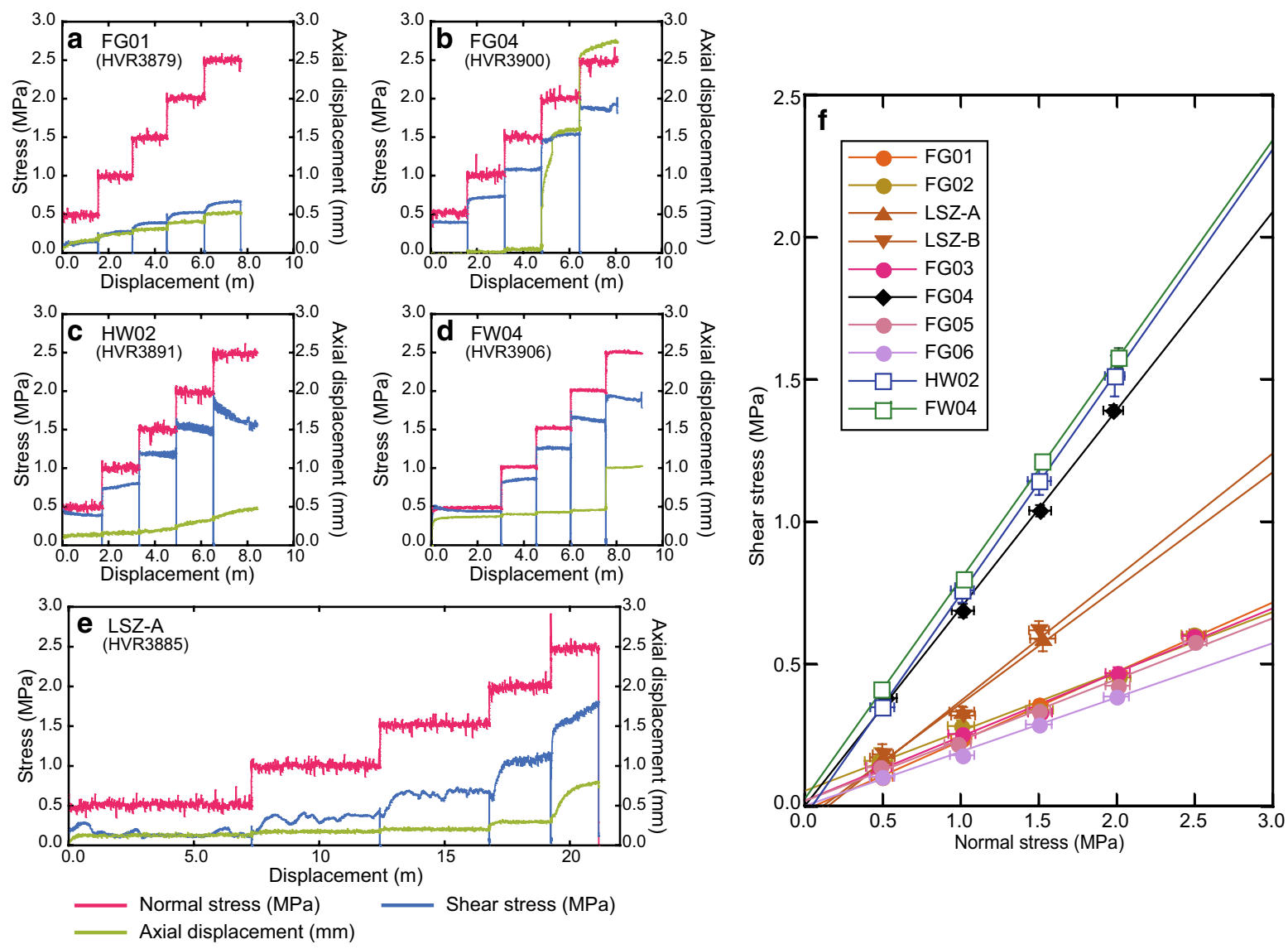

Fig. 3 Frictional behavior of fault-zone materials and surrounding protoliths. Change of shear stress with slip displacement for samples a FG1, light

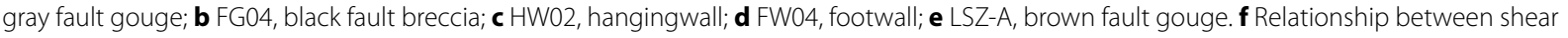
stress and normal stress during frictional slip. Sample locations are shown in Fig. 1c 


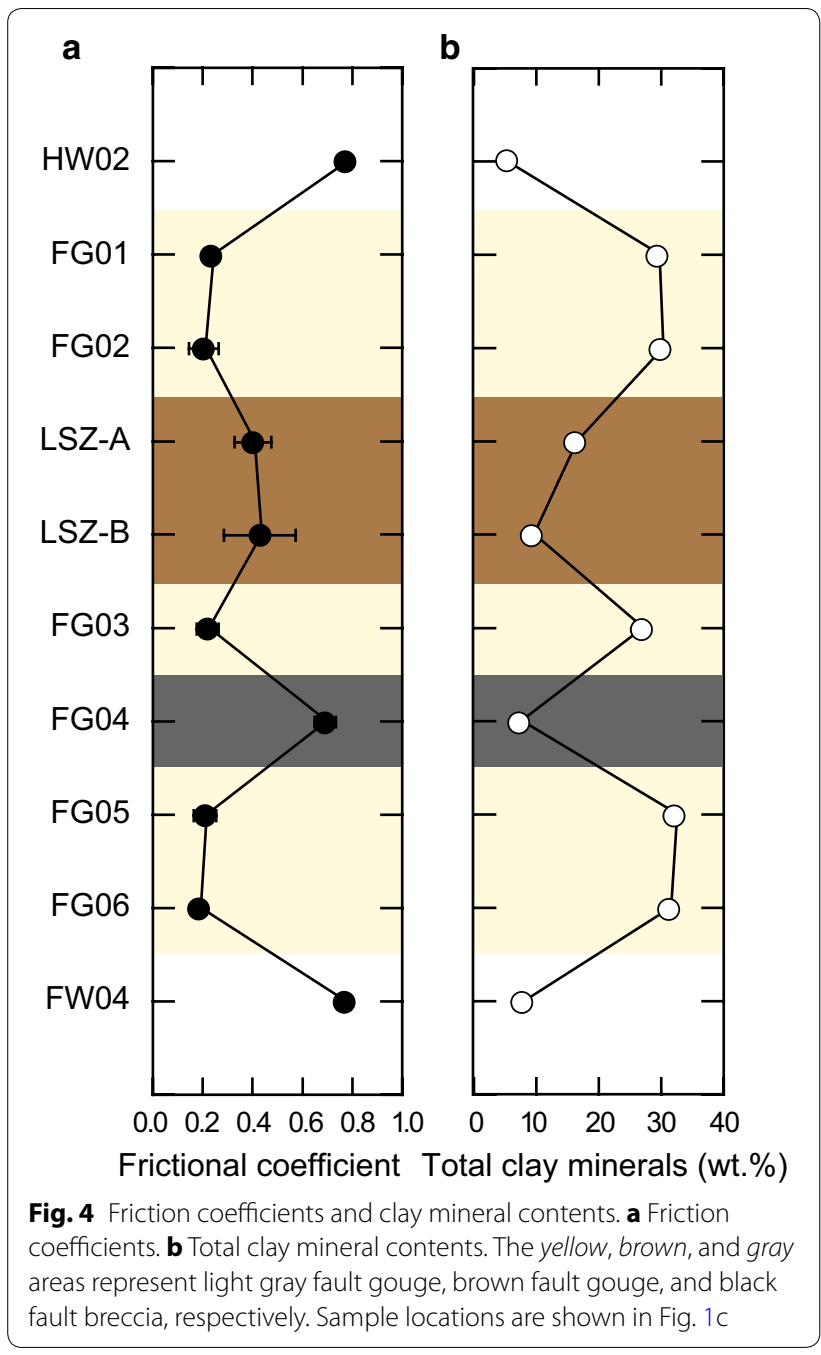

(sample FG04) near its center, a material with a relatively high friction coefficient and low clay mineral content. In addition, the breccia pinches out laterally between the brown gouge and the hangingwall (Fig. 5a). On a mesoscopic scale, the breccia is composed of angular quartz and feldspar grains with a clayey matrix and does not display shear fabric (see Figure 2 of Kato et al. 2015). In thin section, the grain size, mineral species, and texture of the breccia resemble those of the hangingwall host rock (Fig. 5b-e), and their mineral assemblages determined from X-ray patterns likewise coincide (Fig. 2). We conclude that the black fault gouge originated from the hangingwall granite.

The major and trace element concentrations in and around the fault zone were analyzed by Kato et al. (2015), and the chondrite-normalized rare-earth element (REE) patterns of the fault-zone materials and surrounding host rocks resembled each other. These REE patterns are typical of granitic rocks and are consistent with those
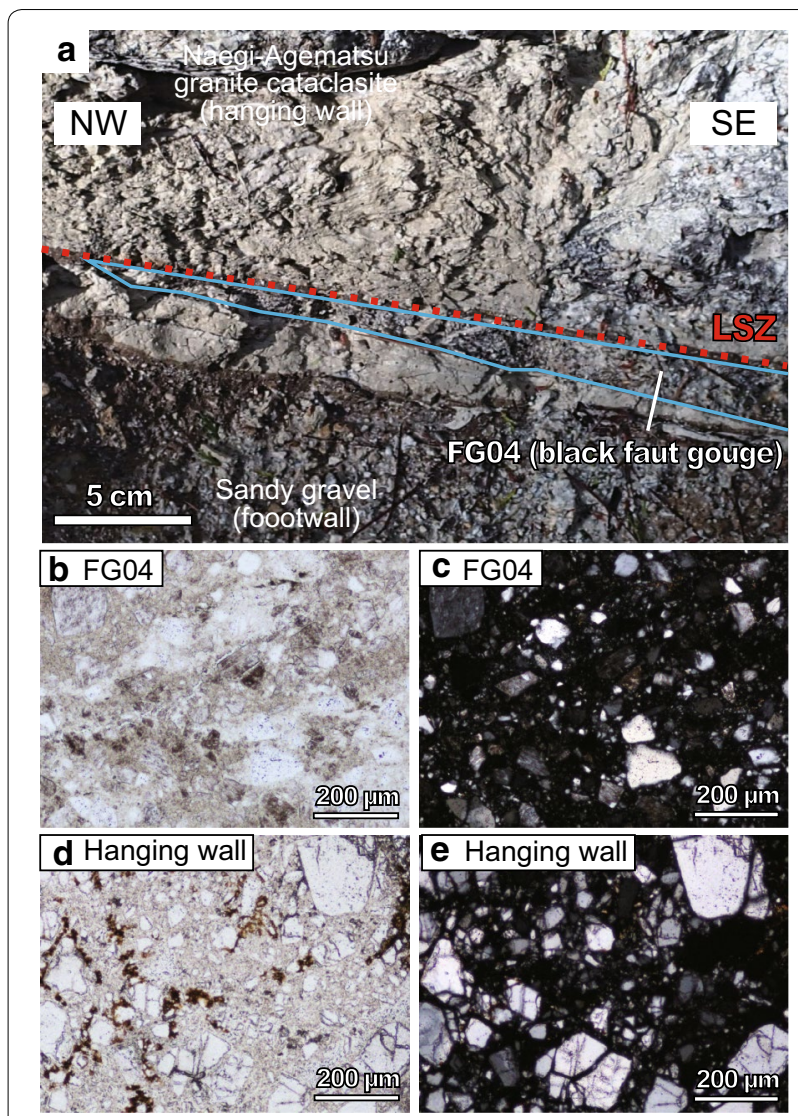

Fig. 5 Mesoscale and microscale structures of the black fault breccia. a Detail of Fig. 1c showing the pinchout of the black fault breccia against the LSZ and hangingwall. b, c Microscopic images of the black fault breccia in plane- and cross-polarized light, respectively. d, e Microscopic images of the hangingwall granite in plane- and cross-polarized light, respectively

of Ryoke granites reported by Ishihara and Murakami (2006). These features could indicate that fault-zone materials and rocks of the footwall sediments were basically originated from the hangingwall granite (Kato et al. 2015). This could also support that the black fault breccia was derived from the hangingwall granite.

As earthquakes repeat, progressive damage may lead to the development of a thicker fault core. It is well known that thicker fault zones have generally accommodated greater cumulative slip displacements (Scholz 1982, 1987; Hull 1988). Even though the intensity of deformation decreases exponentially with distance from the fault core (Vermilye and Scholz 1998), frictional sliding may cause damage to the surrounding host rock and erode its surface. In addition, because of the fractal nature of the boundary surface between a fault zone and host rocks (e.g., Power et al. 1987), there will always be places where asperities are in direct contact across the fault (Scholz 2002). In the Atera fault at Tase, the fault 
zone has an irregular contact with the hangingwall granite, but the latest slip zone cuts the older fault gouges and locally abuts the hangingwall (Figs. 1c, 5c), showing that the surrounding protolith was mechanically incorporated into the fault zone at the mesoscale. This is evidenced by similar REE patterns of the black fault breccia and of the hangingwall granite (Kato et al. 2015). Such incorporation of high friction material could cause the heterogeneity in friction strength of fault zones and might contribute to the evolution of fault-zone architecture.

On the other hand, clay minerals, commonly the dominant component in fault gouge, originate by incorporation of clays from the protolith and by dissolution-precipitation reactions during and after faulting (Vrolijk and van der Pluijm 1999). Authigenic secondary minerals such as smectite have been observed to form following the breakdown of quartz and feldspar during laboratory shear experiments (Tenthorey et al. 1998). During seismic slip, ultrafine particles of amorphous material may be produced by comminution, granulation, and mineral lattice distortion (Yund et al. 1990; Hirono et al. 2014b). Amorphous particles are much more easily dissolved than crystalline grains of equivalent size (Icenhower and Dove 2000), promoting the formation of secondary minerals such as clays by precipitation from fluids in the fault (e.g., Tenthorey et al. 1998; Solum et al. 2005). However, in the Atera fault, no evidence that such amorphous material existed was observed, so this process is in general likely but could not be confirmed in the Atera fault. A negative anomaly of cerium concentration was detected in the light gray fault gouge, probably indicating that smectite and halloysite were precipitated from oxidative fluid of $<110$ and $<80^{\circ} \mathrm{C}$, respectively (Kato et al. 2015).

Experiments have demonstrated that the friction coefficient of a gouge containing clay minerals mixed with sand becomes lower as the clay content increases (Shimamoto and Logan 1981; Takahashi et al. 2007). Low friction coefficients have also been widely reported in natural faults, including $0.1-0.2$ for fault gouge in the San Andreas fault (Carpenter et al. 2015) and 0.3 for fault gouge in the Taiwan Chelungpu fault (Mizoguchi et al. 2008). The low values in the fault gouges of the Atera fault could be ascribed to the presence of large amounts of clay minerals.

\section{Conclusions}

Field observations and laboratory friction experiments show that the active zone of the Atera fault includes a breccia with a relatively high friction coefficient that originated from the hangingwall granite. Although fault zones generally contain large amounts of low friction clay minerals, widespread mesoscale incorporation of surrounding protoliths might cause the heterogeneity in friction strength of fault zones as well as the evolution of fault-zone architectures.

\section{Authors' contributions}

NK and TH performed the fieldwork. NK carried out the friction experiments and microstructure observations. Both authors wrote the paper. Both authors read and approved the final manuscript.

\section{Acknowledgements}

We thank Tomoyuki Ohtani, Tsuyoshi Ishikawa, Jun Kameda, and Wataru Tanikawa for supporting our fieldwork and friction experiment. We also thank Virginia G. Toy and an anonymous reviewer for their constructive reviews. This work was supported by a Grant-in-Aid for Exploratory Research (KAKENHI No. 15K13578) from the Japan Society for the Promotion of Science and by Grantsin-Aid for Scientific Research on Innovative Areas (Crustal Dynamics, KAKENHI No. 26109004) from the Ministry of Education, Culture, Sports, Science and Technology of Japan.

\section{Competing interests}

The authors declare that they have no competing interests.

Received: 14 April 2016 Accepted: 11 July 2016

Published online: 26 July 2016

References

Biegel RL, Sammis CG (2004) Relating fault mechanics to fault zone structure. Adv Geophys 47:65-111. doi:10.1016/S0065-2687(04)47002-2

Borradaile GJ (1981) Particulate flow of rock and the formation of cleavage. Tectonophysics 72:305-321. doi:10.1016/0040-1951(81)90243-2

Bos B, Spiers CJ (2000) Effect of phyllosilicates on fluid-assisted healing of gouge-bearing faults. Earth Planet Sci Lett 184:199-210. doi:10.1016/ S0012-821X(00)00304-6

Boulton C, Carpenter BM, Toy V, Marone C (2012) Physical properties of surface outcrop cataclastic fault rocks, Alpine Fault, New Zealand. Geochem Geophys Geosyst 13:Q01018. doi:10.1029/2011GC003872

Brace WF, Byerlee JD (1966) Stick-slip as a mechanism for earthquakes. Science 153:990-992. doi:10.1126/science.153.3739.990

Brantut N, Schubnel A, Rouzaud JN, Brunet F, Shimamoto T (2008) High-velocity frictional properties of a clay-bearing fault gouge and implications for earthquake mechanics. J Geophys Res 113:B10401. doi:10.1029/200 7JB005551

Brown KM, Kopf A, Underwood MB, Weinberger JL (2003) Compositional and fluid pressure controls on the state of stress on the Nankai subduction thrust: a weak plate boundary. Earth Planet Sci Lett 214:589-603. doi:10.1016/S0012-821X(03)00388-1

Byerlee JD (1978) Friction of rocks. Pure Appl Geophys 116:615-626

Byerlee JD, Brace WF (1968) Stick slip, stable sliding, and earthquakes —effect of rock type, pressure, strain rate, and stiffness. J Geophys Res 73:60316037. doi:10.1029/JB073i018p06031

Carpenter BM, Saffer DM, Marone C (2015) Frictional properties of the active San Andreas Fault, at SAFOD: implications for fault strength and slip behavior. J Geophys Res 120:5273-5289. doi:10.1002/2015JB011963

Collettini C, Niemeijer A, Viti C, Marone C (2009) Fault zone fabric and fault weakness. Nature 462:907-910. doi:10.1038/nature08585

Di Toro G, Han R, Hirose T, De Paola N, Nielsen S, Mizoguchi K, Ferri F, Cocco M, Shimamoto T (2011) Fault lubrication during earthquakes. Nature 471:494-498. doi:10.1038/nature09838

Dieterich JH (1972) Time-dependent friction in rocks. J Geophys Res 77:36903697. doi:10.1029/JB077i020p03690

Eberl DD (2003) User's quide to RockJock - a program for determining quantitative mineralogy from powder X-ray diffraction data. USGS Open-file report $03-78$

Faulkner DR, Jackson CAL, Lunn RJ, Schlische RW, Shipton ZK, Wibberley CAJ, Withjackd MO (2010) A review of recent developments concerning the structure, mechanics and fluid flow properties of fault zones. J Struct Geol 32:1557-1575. doi:10.1016/j.jsg.2010.06.009 
Faulkner DR, Mitchell TM, Behnsen J, Hirose T, Shimamoto T (2011) Stuck in the mud? Earthquake nucleation and propagation through accretionary forearcs. Geophys Res Lett 38:L18303. doi:10.1029/2011GL048552

Han R, Shimamoto T, Hirose T, Ree JH, Ando J (2007) Ultralow friction of carbonate faults caused by thermal decomposition. Science 316:878-881. doi:10.1126/science.1139763

Han R, Hirose T, Jeong GY, Ando J, Mukoyoshi H (2014) Frictional melting of clayey gouge during seismic fault slip: experimental observation and implications. Geophys Res Lett. doi:10.1002/2014GL061246

Hirono T, Fujimoto K, Yokoyama T, Hamada Y, Tanikawa W, Tadai O, Mishima T, Tanimizu M, Lin W, Soh W, Song SR (2008a) Clay mineral reactions caused by frictional heating during an earthquake: an example from the Taiwan Chelungpu fault. Geophys Res Lett 35:L16303. doi:10.1029/2008GL034476

Hirono T, Sakaguchi M, Otsuki K, Sone H, Fujimoto K, Mishima T, Lin W, Tanikawa W, Tanimizu M, Soh W, Yeh E, Song S (2008b) Characterization of slip zone associated with the 1999 Taiwan Chi-Chi earthquake: X-ray CT image analyses and microstructural observations of the Taiwan Chelungpu fault. Tectonophysics 449:63-84. doi:10.1016/j.tecto.2007.12.002

Hirono T, Tanikawa W, Honda G, Kameda J, Fukuda J, Ishikawa T (2013) Importance of mechanochemical effects on fault slip behavior during earthquakes. Geophys Res Lett 40:2988-2992. doi:10.1002/grl.50609

Hirono T, Ishikawa T, Masumoto H, Kameda J, Yabuta H, Mukoyoshi H (2014a) Re-evaluation of frictional heat recorded in the dark gouge of the shallow part of a megasplay fault at the Nankai Trough. Tectonophysics 626:157-169. doi:10.1016/j.tecto.2014.04.020

Hirono T, Kameda J, Kanda H, Tanikawa W, Ishikawa T (2014b) Mineral assemblage anomalies in the slip zone of the 1999 Taiwan Chi-Chi earthquake: ultrafine particles preserved only in the latest slip zone. Geophys Res Lett 41:3052-3059. doi:10.1029/2006GL028050

Hull J (1988) Thickness-displacement relationships for deformation zones. J Struct Geol 10:431-435. doi:10.1016/0191-8141(88)90020-X

Icenhower JP, Dove PM (2000) The dissolution kinetics of amorphous silica into sodium chloride solutions: effects of temperature and ionic strength. Geochim Cosmochim Acta 64:4193-4203. doi:10.1016/ S0016-7037(00)00487-7

Ikari MJ, Niemeijer AR, Marone C (2011) The role of fault zone fabric and lithification state on frictional strength, constitutive behavior, and deformation microstructure. J Geophys Res 116:B08404. doi:10.1029/2011 JB008264

Ikari MJ, Ito Y, Ujiie K, Kopf AJ (2015) Spectrum of slip behaviour in Tohoku fault zone, samples at plate tectonic slip rates. Nat Geosci 8:870-874. doi:10.1038/ngeo 2547

Ishihara S, Murakami H (2006) Fractionated ilmenite-series granites in Southwest Japan: source magma for REE-Sn-W mineralizations. Resour Geol 56:245-256. doi:10.1111/j.1751-3928.2006.tb00282.x

Karner SL, Marone C (2001) Fractional restrengthening in simulated fault gouge: effect of shear load perturbations. J Geophys Res 106:1931919337. doi:10.1029/2001JB000263

Kato N, Hirono T, Ishikawa T, Ohtani T (2015) Mineralogical and geochemical characteristics of the fault gouge at the Tase outcrop, the Atera Fault. Active Fault Res 43:1-16 (in Japanese with English abstract)

Li YG, Vidale JE (2001) Healing of the shallow fault zone from 1994-1998 after the 1992 M7.5 Landers, California, earthquake. Geophys Res Lett 28:2999-3002. doi:10.1029/2001GL012922

Lockner DA, Morrow C, Moore D, Hickman S (2011) Low strength of deep San Andreas fault gouge from SAFOD core. Nature 472:82-85. doi:10.1038/ nature09927

Ma KF, Tanaka H, Song S, Wang C, Hung J, Song Y, Yeh E, Soh W, Sone H, Kuo L, Wu H (2006) Slip zone and energetics of a large earthquake from the Taiwan Chelungpu-fault Drilling Project. Nature 444:473-476. doi:10.1038/ nature05253

Mizoguchi K, Hirose T, Shimamoto T, Fukuyama E (2007) Reconstruction of seismic faulting by high-velocity friction, experiments: an example of the 1995 Kobe earthquake. Geophys Res Lett 34:L01308. doi:10.1029/20 06GL027931

Mizoguchi K, Takahashi M, Tanikawa W, Masuda K, Song SR, Soh W (2008) Frictional strength of fault gouge in Taiwan Chelungpu fault obtained from TCDP Hole B. Tectonophysics 460:198-205. doi:10.1016/j.tecto.2008.08.009

Mizoguchi K, Hirose T, Shimamoto T, Fukuyama E (2009) High-velocity frictional behavior and microstructure evolution of fault gouge obtained from Nojima fault, southwest Japan. Tectonophysics 471:285-296. doi:10.1016/j.tecto.2009.02.033
Muhuri SK, Dewers TA, Scott TE Jr, Reches Z (2003) Interseismic fault strengthening and earthquake-slip instability: friction or cohesion? Geology 31:881-884. doi:10.1130/G19601.1

Niemeijer A, Marone C, Elsworth D (2008) Healing of simulated fault gouges aided by pressure solution: results from rock analogue experiments. J Geophys Res 113:B04204. doi:10.1029/2007JB005376

Niemeijer A, Di Toro G, Griffith WA, Bistacchi A, Smith SAF, Nielsen S (2012) Inferring earthquake physics and chemistry using an integrated field and laboratory approach. J Struct Geol 39:2-36. doi:10.1016/j.jsg.2012.02.018

Olsen MP, Scholz CH, Léger A (1998) Healing and sealing of a simulated fault gouge under hydrothermal conditions: implications for fault healing. J Geophys Res 103:7421-7430. doi:10.1029/97JB03402

Oohashi K, Hirose T, Takahashi M, Tanikawa W (2015) Dynamic weakening of smectite-bearing faults at intermediate velocities: implications for subduction zone earthquakes. J Geophys Res 120:1572-1586. doi:10.100 2/2015JB011881

Power WL, Tullis TE, Brown SR, Boitnott GN, Scholz CH (1987) Roughness of natural fault surfaces. Geophys Res Lett 14:29-32. doi:10.1029/GL014i001 p00029

Reches Z, Lockner DA (2010) Fault weakening and earthquake instability by powder lubrication. Nature 467:452-455. doi:10.1038/nature09348

Rowe CD, Griffith WA (2015) Do faults preserve a record of seismic slip: a second opinion. J Struct Geol 78:1-26. doi:10.1016/j.jsg.2015.06.006

Rutter EH, Maddock RH, Hall SH, White SH (1986) Comparative microstructures of natural and experimentally produced clay-bearing fault gouges. Pure appl Geophys 124:3-30

Scholz CH (1982) Scaling laws for large earthquakes: consequences for physical models. Bull Seismol Soc Am 72:1-14

Scholz CH (1987) Wear and gouge formation in brittle faulting. Geology 15:493-495

Scholz CH (2002) The mechanisms of earthquake faulting. Cambridge Univ Press, New York

Shimamoto T, Logan JM (1981) Effects of simulated fault gouge on the sliding behavior of Tennessee sandstone: nonclay gouges. J Geophys Res 86:2902-2914. doi:10.1029/JB086iB04p02902

Sibson RH (1973) Interactions between temperature and fluid pressure during earthquake faulting — a mechanism for partial or total stress relief. Nature 243:66-68. doi:10.1038/physci243066a0

Solum JG, van der Pluijm BA, Peacor DR (2005) Neocrystallization, fabrics and age of clay minerals from an exposure of the Moab Fault, Utah. J Struct Geol 27:1563-1576. doi:10.1016/j.jsg.2005.05.002

Sugimura A, Matsuda T (1965) Atera fault and its displacement vectors. Geol Soc Am Bull 76:509-522

Tadokoro K, Ando M (2002) Evidence for rapid fault healing derived from temporal changes in S wave splitting. Geophys Res Lett 29:6-1-6-4. doi:1 0.1029/2001GL013644

Takahashi M, Mizoguchi M, Kitamura K, Masuda K (2007) Effects of clay content on the frictional strength and fluid transport property of faults. J Geophys Res 112:B08206. doi:10.1029/2006JB004678

Tenthorey E, Scholz CH, Aharonov E, Léger A (1998) Precipitation sealing and diagenesis: 1. Experimental results. J Geophys Res 103:23951-23967. doi:10.1029/98JB02229

Toda S, Inoue D (1994) The latest activity of the Atera fault: a possibility of the 1586 Tensho earthquake. Zisin 47:73-77 (in Japanese with English abstract)

Toda S, Inoue D (1995) Paleoseismicity of the Atera fault system and 1586 Tensho earthquake: trenching studies at Ogo, Aonohara and Dendahara, Central Japan. Zisin 48:401-421 (in Japanese with English abstract)

Tsukuda E, Awata Y, Yamazaki H, Sugiyama Y, Shimokawa K, Mizuno K (1993) Strip map of the Atera fault system. Geol Surv Jpn Tectonic Map Series 7:1-39 (in Japanese)

Vermilye JM, Scholz CH (1998) The process zone: a microstructural view of fault growth. J Geophys Res 103:12223-12237. doi:10.1029/98JB00957

Vrolijk P, van der Pluijm BA (1999) Clay gouge. J Struct Geol 21:1039-1048. doi:10.1016/S0191-8141(99)00103-0

Wibberley CAJ, Shimamoto T (2005) Earthquake slip weakening and asperities explained by thermal pressurization. Nature 436:689-692. doi:10.1038/ nature03901

Yund RA, Blanpied ML, Tullis TE, Weeks JD (1990) Amorphous material in high strain experimental fault gouges. J Geophys Res 95:15589-15602. doi:10.1029/JB095iB10p15589 